\title{
Public participation in Malawi's environmental impact assessment (EIA) process
}

\author{
I. B. M. Kosamu*, A. A. Mkandawire, W. Utembe and H. W. T. Mapoma \\ University of Malawi Polytechnic, Private Bag 303, Blantyre 3, Malawi.
}

Accepted 10 May, 2013

\begin{abstract}
Since the adoption of the Environmental Management Act of 1996, Malawi has been using environmental impact assessment (EIA) as a tool for predicting and assessing the impact of development projects on the environment. This study assessed the extent of public participation in Malawi's EIA process. Desktop study of relevant documents such as EIA and environmental audit reports, policies and laws, books, journals and internet articles was done. Further information was obtained from relevant stakeholders through interviews and questionnaires. This involved fifteen respondents divided into three categories: five NCE members, five TCE members and five EIA practitioners. This study reveals that public participation is not adequate at most of the key stages of the EIA process in Malawi which puts the human and ecosystem health at risk. There is an urgent need to enforce the EIA provision as stipulated Malawi's Environmental Management Act. Effort should focus on public awareness and human resource capacity development so that the EIA process is diligently executed and that enforcement and follow-ups are properly done by the Department of Environmental Affairs which is a lead agency on environmental issues in Malawi.
\end{abstract}

Key words: Public participation, environmental impact assessment, Malawi, enforcement.

\section{INTRODUCTION}

Most African countries, including Kenya, South Africa, Tanzania, and Nigeria, have done extensive research on public participation in their environmental impact assessment (EIA) process (Murombo, 2008). However, studies to look at the extent of public participation in EIA activities in Malawi are not existent. Since the implementation of the EMA in 1996, Malawi has had a number of development projects including Kayelekera Uranium Mining Project and the construction of Nsanje World Inland Port. The latter project is meant to connect the Shire River in southern Malawi to the Indian Ocean. Besides that, Malawi parliament recently passed a bill to allow for an extensive feasibility study on the possibility of starting oil extraction activities on Lake Malawi.
For such projects EIA procedures are mandatory and public participation plays a significant role in these processes. This is so because people may be affected, for example, re-allocation, exposure to radiation, contamination of potable water sources and creation of employment opportunities (Carroll and Turpin, 2009). The EMA stipulates the procedure for EIA and makes provisions for its implementation and enforcement. EIA provisions in the EMA are found in Sections 24 (projects for which an EIA may be required), 25 (EIA reports), 26 (review of EIA reports), 27 (environmental audits), 28(monitoring existing projects), 29 (fees), 63 (penalties), 76 (closures) and 77 responsibilities. As such Malawi has its own EIA guidelines published in 1997 which provide

*Corresponding author. ikosamu@poly.ac.mw. Telephone: +265 1870 411. Fax: +265 1870578.

Abbreviations: NCE, National Council for the Environment; TCE, Technical Committee on the Environment. 
the code of conduct for public consultation in line with the section 52 of EMA that stipulates public access to information and participation. The level of public participation on EIA issues in such development projects in Malawi is far from clear. It is not surprising therefore that in several projects including the Kayelekera uranium mining project in northern Malawi and the Kapani meat processing facility in the southern city of Blantyre, the lack of public information on potential costs and benefits of development projects has resulted in popular disapproval of otherwise helpful initiatives.

EIA as a tool for sustainable development was adopted much later in developing countries (IAIA, 2006; Glucker, 2012) resulting in most development projects taking place without any EIA (Appiah-Opuku, 2001). In most projects, EIAs were conducted as a precondition from donor and multilateral development agencies (World Bank, 1993). This happened until EIA as a procedure was adopted by most countries during the "post Agenda 21" era in the 1990s (Kakonge, 1996; Tarr, 2003). 'Public participation' has been defined in this study as a process of engagement, where people are enlisted into the decision making process; requiring that those initiating it are open to the potential need for information exchange and are prepared to work with different interests to develop plans or to amend or even drop existing proposals (Petts, 1999). Glasson et al. (2005) emphasize the need for consultation and participation at all stages of the EIA process. This study therefore assessed the extent of public participation in Malawi's EIA process.

\section{MATERIALS AND METHODS}

This study used both qualitative and quantitative data collection methods based on multi-stage (two-stage) sampling technique. From the EIA and Environmental Audit reports produced per year from 2001-2012, a total of 60 reports were randomly selected and analysed. An average number of reports were produced per year. At least fifteen members from the TCE, the NCE, and EIA officers/experts (five interviewees from each category) were also interviewed. Such triangulation is important for ensuring objectivity and representativeness of data.

\section{Description of sample}

Forty-five EIA and fifteen Environmental Audit reports for mining, waste disposal, road construction, and water resources and irrigation scheme and residential area development projects were analysed using criteria by Wood (1995). Further information was obtained using both structured and unstructured interviews as well as through a questionnaire for a range of highly knowledgeable experts in the field who could identify key issues in EIA policies, legislation and practice that are related to public participation, health impacts and their assessment and sustainable development. Some of the issues covered include: Is the public consulted? At which stage(s) of the EIA process is the public consulted/allowed to participate in Malawi's EIA system? What are the major challenges facing public participation process in Malawi EIA system? What are the opportunities for the success of public participation in Malawi's EIA System?

Every effort was made to involve respondents with the most extensive experience, that is, those recognized by their peers as having the extensive expertise in the field. Altogether fifteen respondents were interviewed.

\section{Data analysis}

The qualitative data was analyzed by organizing the information and identifying the pattern, developing relevant themes and drawing conclusions. The quantitative data was analyzed using Microsoft Excel (2007) which was presented in the form of charts and tables.

\section{RESULTS AND DISCUSSION}

\section{Categories of respondents}

Data was captured at five levels of respondents, each of which was made up of various categories or groups which took part in the public participation process. These levels are outlined below.

\section{Project area's information/projects' surrounding area}

This level looked at the number of people involved in the process of public consultation from affected and surrounding communities and/or villages as well as people involved from the administrative offices of the central government.

\section{Institutional libraries}

This level looked at public involvement from surrounding primary, secondary and tertiary academic institutions across the country.

\section{National/local libraries}

This category comprised people who forwarded comments, questions and concerns pertaining to the consequences (both positive and negative) of a particular development using public consultation forms placed at local and/or national libraries present in Malawi.

\section{Local institutions and NGO's}

This category was concerned with participants from environmental and human rights NGOs, health institutions (example Malawi's ministry of health), water and sanitation NGOs, trade unions, religious groups, legal institutions, companies, security institutions, media houses, political parties, welfare organizations, statutory 


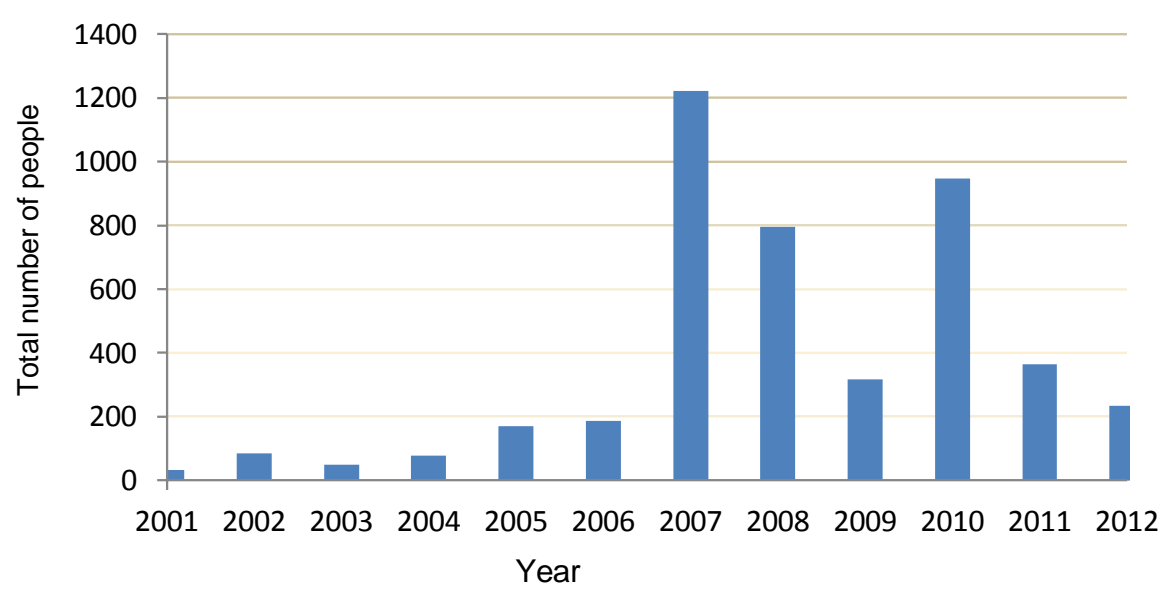

Figure 1. Total number of people consulted each year from 2001-2012.

co-operations and key government departments.

\section{Other sources}

This level concentrated on participants from International NGOs and/ or agencies, government ministries, local and/ or international EIA experts, international or outside universities.

Figure 1 presents the number of people that were consulted as indicated in the 60 reports that were submitted to the Department of Environmental Affairs between the years 2001 and 2012.

Figure 1 indicates that public participation was highest in 2007 but the trend decreased with fewer people being consulted in 2012. This is a worrisome scenario as it reflects less incorporation of people's views in project planning and implementation.

\section{Results for the key issues identified}

\section{Importance of public participation in EIA}

Respondents were asked on how they would rate Public participation in Malawi's EIA System. $80 \%(n=12)$ showed that it is very important while $20 \%(n=3)$ rated it as just being important as shown in Figure 2.

\section{Success of public participation in Malawi's EIA System}

When asked about the success of public participation in Malawi's EIA process, $40 \%(n=6)$ answered that it is successful, another $40 \%(n=6)$ said it is fairly successful, $13 \%(n=2)$ said it is not successful and $7 \%$ $(n=1)$ of the respondents did not respond to this question (hence, $\mathrm{N} / \mathrm{A}=$ not applicable) and this information is shown in Figure 3.

An in depth analysis showed that the responses were based on the following issues:

Successful: The respondents said public participation in EIA is successful because of such reasons as: Department of Environmental Affairs' co-ordination with stakeholders, key stakeholders are normally consulted in the EIA studies, key stakeholders participate in implementation of mitigation measures and some projects' design have been modified based on the recommendation from public participation.

Fairly Successful: Under this rating, respondents attributed the reasons to less time being spent on consultation, that is limited time is allocated to communities to participate; inability of the consultants to consult the right people; unwillingness of the public members to participate since they do not know the importance of public participation in EIA (as a result of low public awareness), low priority accorded to environmental issues by the government, and that most of the communities' views are not taken aboard in the preparation of EIA and Environmental Audit reports.

Not Successful: The reasons alluded to this rating included: participation is only done to fulfill legal requirements, that is, it is pseudo-participation and is closely related to what is called "pseudo- alternatives" (Murombo, 2008); monitoring of public participation process in not effectively done by the government agent (EAD) and also due to inadequacy of human and financial resources. This is consistent with the findings of Kosamu (2011). 


\section{Important}

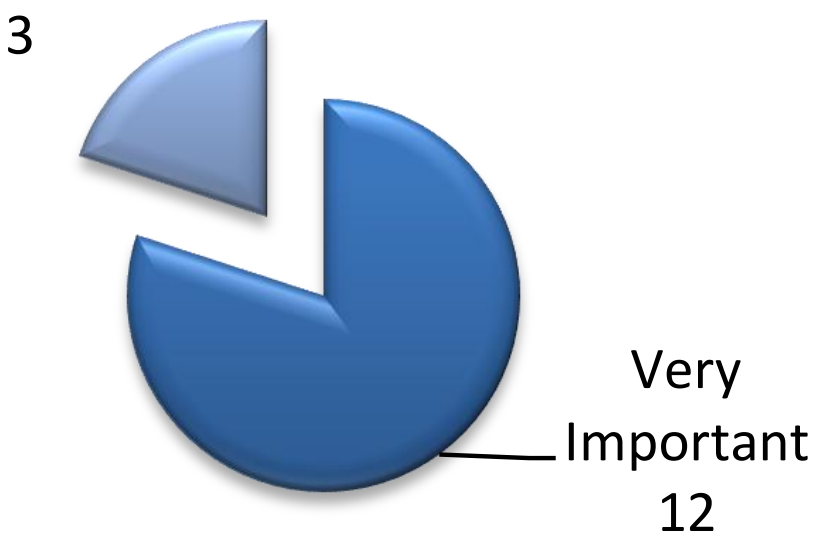

Figure 2. Rating of Public Participation in Malawi by respondents.

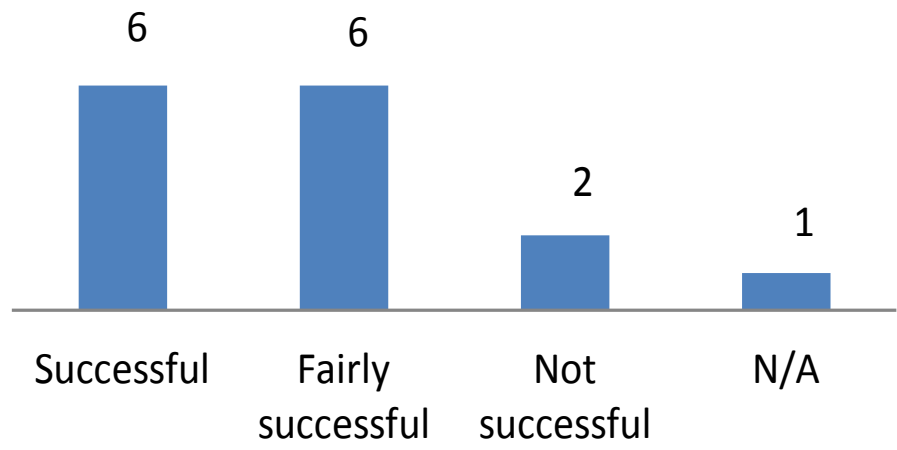

Figure 3. Success of Public Participation in EIA in Malawi.

\section{Stages of the EIA process at which the public is consulted in Malawi's EIA system}

The respondents indicated that public participation is done during various stages including: project screening; consideration of alternatives; identification of the main impacts, post-decision monitoring and follow-up; prediction of impacts, mitigation measures; impact analysis; EIA/EA report presentation, decision making and auditing. It was also established that public consultation and participation methods commonly used in Malawi' EIA system are: information notices, community meetings, public hearings, radio stations, manipulative participation, passive participation and participation by use of material incentives.

\section{Challenges facing Public Participation Process in Malawi EIA system}

Upon being asked to provide the challenges and/or limitations faced during public participation in Malawi's EIA system, stakeholders raised many issues and the following is a summary of the major ones: tendency for local chiefs to dominate the discussions thereby barring the views of most ordinary people; inadequate briefing of the projects; high illiteracy of the community members makes it difficult to communicate EIA issues since environmental issues are considered complex; there are no independent monitoring of public participation; sometimes it is difficult to meet relevant people in the field, sometimes projects are required to be implemented quickly due to pressure from donors or politicians hence inadequate time for public participation, technocrats and administrators in the government ministries are not always available for consultations due to their busy schedules; environmental issues are given low priority by the government; there is a shortage of number of expertise who are equipped with the skills of public participation; limited resources which also limits the time and area of coverage during the EIA and lastly, poor communication (example absence of road networks) in some areas such that it is difficult to reach some stakeholders. Most of these challenges have previously been reported by Kosamu (2011).

\section{Opportunities for success of public participation in Malawi's EIA system}

The respondents were also asked to highlight the opportunities present in Malawi for the success of the public participation and consultation. The following is a summary of the responses provided: the EMA is present and needs to be strictly enforced; a regulatory body (EAD) is present and there is a need to boost its functionality by increasing its workforce an financial allocation; government through its community services may assist in conducting awareness campaigns; traditional and political leaders may be used to influence their subjects to participate in EIA activities; and the revision of the EIA legal framework and preparations of clear guidelines for public consultations.

\section{Conclusion}

This study established that public participation in Malawi's EIA process is still very low. However, a number of opportunities and interventions exist which can make public participation a successful approach. Planners of development projects should ensure that incentives for public participation are established. This can be fostered through oral and written briefings and discussions with local people to obtain advice and consent to foster local project ownership and participation.

As a lead agency, the EAD has to make sure that EIA procedures are critically followed by the project 
developers. The workforce at the EAD also needs to be blended with expertise from different fields so that there is adequate consensus on issues raised by the public.

\section{ACKNOWLEDGEMENTS}

Authors would like to thank the University of Malawi for financially supporting this study.

\section{REFERENCES}

Appiah-Opoku S (2001). Environmental Impact Assessment in Developing Countries: The case of Ghana. Environ. Impact Assess. Rev. 21:59-71.

Carroll B, Turpin T (2009). Environmentallmpact Assessment Handbook: A Practical Guide for Planners, Developers, and Communities. $2^{\text {nd }}$ ed. Thomas Telford Limited, USA.

Glasson J, Therivel R, Chadwick A (2005). Introduction to Environmental Impact Assessment. $3^{\text {rd }}$ ed. Routledge Taylor and Francis Group, London.

Glucker A N (2012). Public participation in Environmental Impact Assessment (EIA) - An investigation into theory and practice in Costa Rica and Nicaragua. MSc. Thesis, University of Utrecht, The Netherlands.

IAIA (2006). Public participation. International Best Practice Principles. Special Publication Series No. 4. Available at: http://www.iaia.org/publicdocuments/specialpublications/SP4\%20web.pdf.

Kakonge JO (1996). Problems with Public Participation in EIA Process: Examples from Sub-Saharan Africa. Impact Assessment, Volume, 14. Available at: http://www.ttl.fi/Internet/English/Information/Electronic+journals/Africa +Newsletter/2000-03/03.htm.
Kosamu IBM (2011). Environmental impact assessment application in infrastructural projects in Malawi. Sustain. Sci. 6(1):51-57.

Lee N, George C (2000). Environmental Assessment in Developing and Transitional countries. New York: Wiley \& Sons.

Leu WS, Williams WP, Bark AW (1997). Evaluation of environmental impact assessment in three Southeast Asian Nations. Project Appraisal 12(2):89-100.

Murombo T (2008). Beyond Public Participation: The Disjuncture between South Africa's Environmental Impact Assessment (EIA) Law and Sustainable Development. Potchefstroom Electronic Law J. (PER), 3:1-31. ISSN 1727-3781.

Petts J (1999). Public Participation and Environmental Impact Assessment. In Petts, J. (ed.): Handbook of Environmental Impact Assessment Practice: Impact and Limitations (Vol. 1). Blackwell Science Limited, USA.

Sankoh OA (1996). Making Environmental Impact Assessment Convincible to Developing Countries. J. Environ. Manage. 47:185189.

Tarr P (2003). EIA in southern Africa: Summary and future focus. In Southern African Institute for Environmental Assessment: Environmental Impact Assessment in Southern Africa. Windhoek, Southern African Institute for Environmental Assessment, pp. 329337.

Wood C (1995). Environmental Impact Assessment: A Comparative Review. Longman Group Ltd., Harlow, UK.

World Bank (1993). Public Involvement in Environmental Assessment: Requirements, Opportunities and Issues. Environmental Assessment Sourcebook Update 5. Environmental Department, World Bank, Washington DC. 